\title{
ARGUMEN EKSISTENSI TUHAN DALAM FILSAFAT BARAT
}

\section{Supian}

Fakultas Ilmu Budaya Universitas Jambi

Email: supian_ramli@yahoo.co.id

\begin{abstract}
The debate about the existence of God is important because it is the key to all doors study of religion as a whole. Every religion will begin with a discussion of beliefs about the existence of God. If believed in the existence of God, then someone legitimately be called religion (theism), and when to deny the existence of God, then the person can be classified to reject religion or no religion (atheism). This article is intended to explore the history and ideas of the philosophers of the West in giving arguments for God's existence. This study found that the existence of God in a variety of Western philosophical thinking has sparked a serious debate involving the realm of the mind and heart.
\end{abstract}

\begin{abstract}
Perdebatan tentang eksistensi Tuhan menjadi penting karena merupakan kunci dari semua pintu kajian tentang agama secara keseluruhan. Setiap agama akan dimulai dari pembahasan tentang keyakinan tentang eksistensi Tuhan. Apabila meyakini eksistensi Tuhan, maka seseorang secara sah disebut beragama (theism), dan apabila menolak eksistensi Tuhan, maka seseorang dapat digolongkan kepada menolak agama atau tidak beragama (atheism). Artikel ini dimaksudkan untuk menyelami sejarah dan pemikiran para filosof Barat dalam memberikan argumenargumen eksistensi Tuhan. Kajian ini menemukan bahwa eksistensi Tuhan dalam berbagai pemikiran filsafat Barat telah memicu perdebatan serius yang melibatkan ranah akal dan hati.
\end{abstract}

Kata Kunci: Filsafat, Akal, Hati, Eksistensi Tuhan, Filosof Barat

\section{Pendahuluan}

Persoalan eksistensi Tuhan merupakan masalah yang sangat mendasar, luas dan serius dalam kajian filsafat, khususnya filsafat 
agama ${ }^{1}$. Kajian-kajian mengenai eksistensi Tuhan menjadi kajian yang tidak akan pernah selesai sampai kiamat datang. Apakah kajian itu dilihat dari aspek dogma semata, dilihat dari aspek akal semata, ataupun dilihat dari aspek dogma dan akal sekaligus. Belum lagi apabila dilihat dari aspek yang meyakini eksistensi Tuhan, dan sebaliknya dari aspek yang mengingkari eksistensi Tuhan. Berbagai argumen dan penalaran yang dikemukakan secara panjang lebar telah menjadi bagian dari kajian mengenai eksistensi Tuhan sepanjang masa. Terdapat banyak argumen yang didapatkan dari dogma agama sebagaimana yang disampaikan oleh para teolog, demikian pula banyak argumen yang dimunculkan dari teori para filosof.

Bertrand Russell ${ }^{2}$ misalnya, mengemukakan penentangannya terhadap agama dalam debat publik dengan para tokoh agama terkemuka dan merasa senang membuat sindiran-sindiran anti agama, seperti ia mengatakan bahwa jika ia dibawa ke hadapan Tahta Langit (Tuhan), ia akan menegur Penciptanya karena tidak menyediakan cukup bukti akan eksistensi-Nya. Tetapi di sisi lain, Russell juga pernah berkata bahwa ketika seseorang berpikir tentang Tuhan, maka ia tidak boleh berpikir tentang Tuhan sebagai Tuhan salah satu planet atau Tuhan salah satu agama, suku dan daerah tertentu di planet ini. Karena yang demikian itu tidak akan pernah menjelaskan tentang eksistensi Tuhan yang sesungguhnya. Tetapi seseorang harus berpikir secara utuh dan menjadi kesimpulan dari sudut pandang seluruh kosmos, yakni berpikir tentang Tuhan sebagai Tuhan seluruh alam. ${ }^{3}$

Upaya untuk membuktikan sesuatu itu benar atau ada merupakan hal yang selalu menarik. Membuktikan sesuatu itu benar, berarti menunjukkan kepastian di mana sebelumnya terdapat ketidakpastain, dan membuktikan sesuatu itu ada, berarti menunjukkan kepastian adanya, di mana sebelumnya terdapat keraguan atau ketidakpastian. Umumnya bukti yang dapat dianggap pasti adalah bukti matematis dan kebendaan, begitu juga dengan bukti penelitian ilmiah, dapat

${ }^{1}$ Hampir setiap buku filsafat Agama menempatkan pembahasan tentang eksistensi Tuhan pada awal kajian dan kajian utama. Seperti Michael J. Murray \& Michael Rea. An Introduction to The Philosophy of Religion. (Cambridge: Cambridge University Press, 2008), 1-57.

2Sebagaimana terdapat dalam Louis Greenspan \& Stefan Anderson. Russell on Religion. Terj. Bertuban Tanpa Agama, Esai-Esai Bertrand Russell (Yogyakarta: Resist Book, 2009). 169

${ }^{3}$ Louis Greenspan \& Stefan Anderson. Russell on Religion. Terj. Bertuban Tanpa Agama, 102. 
diperlakukan sesbagi sesuatu yang sangat mendekati (bighly probable) ${ }^{4}$, seperti menunjukkan keberhasilan suatu percobaan, tetapi tidak berarti sama hasilnya apabila dilakukan di masa-masa selanjutnya.

Tetapi bagaimana dengan bukti filosofis? Selama berabad-abad para filsosof dan teolog menggulati upaya untuk membuktikan eksistensi Tuhan. Beberapa pemikir besar yang pernah hidup telah membaca dengan rajin dan berjuang secara ilmiah untuk membuktikan hal ini, dan sebagaimana jelas, membuktikan hal ini merupakan hal yang sangat berbeda dari pembuktian mengenai hal lain. Pembuktian yang dilakukan oleh para filosof, yakni dengan mengajukan argumen-argumen ilmiah dan filosofis. Meskipun demikian, tidak semua para pemikir dan filosof tersebut bermuara kepada satu kesimpulan dan argumen yang sama, sehingga kajian ini kemudian menjadikan satu disiplin ilmu tersendiri yang disebut filsafat agama, yakni studi yang membahas tentang dasar-dasar agama ${ }^{5}$.

\section{Theisme vis a vis Atheisme}

Mempertemukan atau menggandengkan antara theisme dengan atheisme secara filosofis dan ilmiah tentu saja merupakan sesuatu yang sangat sulit (atau bahkan tidak mungkin) untuk dilakukan, karena sepertinya antara theisme dan atheisme sudah mempunyai bangunan masing-masing, bangunan yang kokoh dengan penghuni yang telah pula mempunyai jati diri dan karakteristik masing-masing. Membandingkan keduanya juga merupakan sesuatu yang mustahil, karena memang keduanya sudah jelas memiliki perbedaan, begitupun

${ }^{4}$ Linda Smith \& William Raeper. A Beginner's Guide to Ideas. Terj. Ide-ide Filsafat dan Agama Dulu dan Sekarang. Cet. 4. (Yogyakarta: Penerbit Kanisius, 2004), 39.

${ }^{5}$ Menurut Harun Nasution, membahas dasar-dasar agama tersebut dilakukan secara analitis dan kritis, dengan maksud untuk menyatakan kebenaran ajaran-ajaran agama, atau sekurang-kurangnya untuk menjelaskan bahwa apa yang diajarkan agama tidaklah mustahil dan tidak bertentangan dengan logika. Perbedaannya dengan teologi adalah bahwa (i) filsafat agama tidak membahas dasar-dasar agama tertentu, tetapi dasar-dasar agama pada umumnya, edangkan teologi membahas dasar-dasar agama tertentu, dengan demikian ada teologi Islam, teologi Kristen, teologi yahudi dan lain-lain, (ii) filsafat agama bermaksud menyatakan kebenaran atau ketidakbenaran dasar-dasar tersebut, sedangkan teologi menerima kebenaran ajaran itu sudah sebagai suatu kebenaran, tidak memikirkan lagi apa benar atau tidak, teologi hanya bermaksud memberikan penjelasan atau interpretasi tentang dasar-dasar itu. Lebih lanjut lihat Harun Nasution. Falsafat Agama, 4-5

TAJDID Vol. xv, No. 2, Juli - Desember 2016 |229 
apabila ada usaha dan pemikiran untuk menghilangkan salah satu dari keduanya. Hal yang paling mungkin dilakukan adalah dengan memperkuat argumen salah satu dari keduanya, atau dengan kajian deskriptif untuk menjelaskan argumen-argumen yang dipakai oleh keduanya ${ }^{6}$.

Mendudukkan persoalan seperti inilah yang dilakukan dan diakui oleh JJ.C. Smart dan JJ. Haldane, sebelum menulis perdebatan antara atheisme dan theisme ${ }^{7}$. Diawali dengan pertanyaan filosofis (philosophical question): what are atheism and theism?s Keduanya kemudian mengembangkan berbagai argumen dan pendekatan mengenai theisme dan theisme dan argumen-argumen yang diajukan oleh kedua faham tersebut. Sebagai contoh bagaimana keduanya berkontribusi dan menjelaskan tentang realisme metafisika (metaphysical realism), tetapi kemudian membangun tesis yang berbeda. Haldane menyusun argumen-argumen yang kemudian menjadi dasar theisme, sedangkan Smart menyusun argumen-argumen yang kemudian menjadi dasar atheisme. ${ }^{9}$

\section{Argumen Eksistensi Tuhan dalam Filsafat Barat}

Pertanyaan besar dalam kajian filsafat dan metafisika adalah "Apakah Tuban itu ada?" dan "Bagaimana Tuban itu berada?". Dua pertanyaan ini selalu mewabah dan menghinggapi asa pemikiran para filosof (dan teolog) sejak masa Yunani kuno sampai saat ini. Sebenarnya pertanyaan dan konsep-konsep utama filsafat seperti ini telah ada ribuan tahun sebelum tercatat secara historis. ${ }^{10}$ Sejak

${ }^{6}$ Dalam hal ini dapat dicontohkan dalam karya J.J.C. Smart \& J.J. Haldane. Atheisme and Theisme, Second Edition. (Oxford, et.all: Blackwell Publishing, 2003). Dan Jordan Howard Sobel. Logic and Theism, Arguments For and Against Beliefs in God. (Cambridge: Cambridge University Press, $\mathrm{tt}$ ).

7J.J.C. Smart \& J.J. Haldane. Atheisme and Theisme, Second Edition (Oxford, et.all: Blackwell Publishing, 2003). 5

${ }^{8}$ Baca lebih lanjut lagi buku ini secara lengkap: J.J.C. Smart \& J.J. Haldane. Atheisme and Theisme (Oxford, et.all: Blackwell Publishing, 2003).

${ }^{9}$ Haldane membahas hal tersebut dalam bagian pertama buku Atheisme and Theisme, hal. 6-75. Sedangkan Smart membahasnya pada bagian kedua, hal. 76150. Dan pada bagian ketiga (hal. 151-170) Smart mereply Haldane, kemudian pada bagian keempat (hal. 171- 220) giliran Haldane mereply Smart.

${ }^{10}$ Robert C. Solomon \& Kathleen M. Higgins, A Short History of Philosophy.

Terj. Sejarah Filsafat. (Yogyakarta: Yayasan Bentang Budaya, 2002), Pada pengantar hal. vii. Buku ini memuat sejarah singkat filsafat sejak berabad-abad 
puluhan ribu tahun yang lalu manusia telah mengembangkan pengertian tentang Tuhan, dewa-dewa, tentang kehidupan sesudah mati.

Semua argumen dari argumen eksistensi Tuhan yang diperkenalkan dan disampaikan oleh para filosof memang tidak dapat membuktikan adanya Tuhan secara fisik, tetapi memperlihatkan bahwa hubungan antara manusia dengan Tuhan dan pada gilirannya membuktikan bahwa Tuhan itu ada menjadi dapat diterima oleh akal. Argumen para filosof menjelaskan mungkinnya relasi manusia dengan Tuhan yang transenden dan memperlihatkan sifat rasional dan universal relasi tersebut. Ini dimungkinkan untuk menjawab serta membuka dialog dengan kelompok yang bersikap indiferen terhadap kepercayaan adanya Tuhan (kaum agnostik), atau bahkan juga dengan kelompok yang menolak Tuhan secara argumentatif (kaum atheis). ${ }^{11}$

Refleksi rasional para filosof mengenai eksistensi Tuhan antara lain bermaksud mempertanggungjawabkan penerimaan dan pengakuan adanya Tuhan sebagaimana terdapat dalam ajaran-ajaran agama seperti Islam dan Kristen. Sebab dasar setiap agama adalah faham atau keyakinan tentang Tuhan. Dengan pemahaman ini agama menghubungkan atau menyambungkan kembali ${ }^{12}$ manusia pada asalusul keilahiannya. Dan untuk memantapkan hubungan tersebut sangat penting adanya pandangan yang meyakinkan tentang eksistensi Tuhan. Maka meskipun dengan argumen-argumen pro eksistensi Tuhan, para filosof tidak pernah berusaha dan mampu secara sempurna membuktikan Tuhan seperti ada-Nya dan diimani, namun dengan refleksinya para filosof dapat membantu agama memahami dan mempertanggungjawabkan dasar iman dan kepercayaan manusia.

Para filosof telah hadir sejak masa Yunani kuno, Helenistik (masa pengaruh Yunani), Scholastik (masa pertengahan yang cenderung

Sebelum Masehi hingga kontemporer, dengan kronologi biografis yang dapat dijadikan sebagai pengantar awal mengenai filsafat dan tokoh-tokohnya.

${ }^{11}$ Simon Petrus L. Tjahyadi. Tuhan Para Filsuf dan Ilmuwan, Dari Descartes Sampai Whitehead. Cet. 5. (Yogyakarta: Kanisius, 2011). 13. Simon bahkan membagi kaum atheis menjadi dua, (i) Ateis teoritis, kelompok yang menolak eksistensi Tuhan dengan argumen-argumen teoritis dan filosofis, dan (ii) Ateis praktis, kelompok yang mulutnya mengaku ber-Tuhan, tetapi cara hidup dan prilakunya tidak menghasilkan buah baik yang nyata dari pengakuan itu.

${ }^{12}$ Religion (agama) berasal dari kata re-ligare dalam bahasa Latin yang berarti menghubungkan atau menyambungkan kembali. Sebagaimana dikutip oleh Simon. Tuhan Para Filsuf dan Ilmuwan, 13-14.

TAJDID Vol. xv, No. 2, Juli - Desember 2016 |231 
kepada agama), Islam dan masa Modern hingga kontemporer dewasa ini, dan silih berganti mengajukan tesis tentang eksistensi Tuhan, filosof-filosof besar sejak Thales (636-546 SM), Pythagoras (582-507 SM) dan Socrates (469-399 SM) hingga filosof dunia kontemporer telah menoreh tinta emas filsafat dalam membangun iklim rasional dan filosofis di tengah-tengah umat manusia. Terutama filosof-filosof pro eksistensi Tuhan, antara lain: Plato (427-348 SM, Aristoteles (384322 SM), Anselmus (1033-1109 M), Thomas Aquinas (1225-1274 M), Rene Descartes (1596-1650 M), Benedict Spinoza (1632-1677 M), Immanuel Kant (1724-1804 M) hingga Alfred North Whitehead (1861-1947 M) adalah filosof-filosof yang patut untuk direfleksikan kembali argumen-argumen mereka tentang eksistensi Tuhan. Demikian pula para filosof besar Muslim seperti Al-Kindi, Al-Farabi, Ibnu Sina, Ibnu Rusd hingga filosof Muslim kontemporer yang telah meletakkan tradisi rasional dalam menjelaskan, memahami dan mengimani eksistensi Tuhan.

Sejarah mencatat bahwa Plato dan Aristoteles menjadi dua filosof besar yang dianggap sebagai pendiri filsafat yang paling dikenal. Keduanya boleh jadi merupakan inspirator bagi perkembangan filsafat hingga saat ini. Meskipun masa sebelum mereka sudah terdapat banyak filosof, yang disebut dengan masa Hellenistik, sekaligus menjadi awal berkembangnya filsafat Barat, yang dimulai kira-kira pada awal abad ke VI sebelum Masehi, ${ }^{13}$ namun pemikiran filsafat Plato dan Aristoteles lebih "membumi" dibanding para filosof lain semasanya.

Plato dan Aristoteles juga merupakan dua filosof yang mencari esensi benda-benda dan apa di balik benda-benda yang merupakan urusan akal. Plato membagi dunia menjadi dua; (Pertama) "Dunia Menjadi" (World of Becoming), yang selalu berubah dan tidak permanen, (Kedua) "Dunia Ada" (World of Being), merupakan dunia ideal yang dihuni oleh "Bentuk-bentuk" ideal yang bersifat abadi dan tidak berubah. ${ }^{14}$ Plato pula yang pertama menggunakan istilah theologia, yang telah sampai ke penggunaan modern sebagai teologi. Konsep

${ }^{13}$ Robert C. Solomon \& Kathleen M. Higgins, A Short History of Philosophy. Terj. Sejarah Filsafat. 13.

${ }^{14}$ Robert C. Solomon \& Kathleen M. Higgins, A Short History of Philosophy. Terj. Sejarah Filsafat. 104-105. 
utama Plato tentang eksistensi Tuhan yaitu forma dari Yang Baik, forma tertinggi di dunia forma telah diidentikkannya dengan Tuhan. ${ }^{15}$

Demikian pula Aristoteles, ia memajukan konsep tentang Tuhan sebagai "Penggerak Pertama". Tuhan adalah penggerak yang tidak bergerak, dan dengan argumen teleologis, Aristoteles menjelaskan bahwa Tuhan adalah tujuan akhir dari kosmos ini, Ia satu-satunya bentuk yang berada dalam diri-Nya sendiri dan terpisah dari bahan, Ia yang menjaga planet-planet dan bintang-bintang tetap pada jalurnya, yang mempertahankan kelangsungan hidup di alam semesta. Tuhan itu abadi dan lengkap dalam Diri-Nya sendiri. Dia seluruhnya adalah aktualitas, tujuan akhir, cita-cita dan tujuan dari semua benda yang bergerak dan mencoba mewujudkan potensinya. ${ }^{16}$

\section{Anselmus}

Anselmus adalah pemikir yang paling berarti pada abad ke-11. Ia berkeyakinan bahwa iman berikhtiar menemukan pemahaman atau pengertian. Memang bagi Anselmus iman selalu menjadi titik tolak pemikirannya, dan isi ajaran iman tidak bisa dibantah oleh alasanalasan rasional. Namun, akal budi yang sejati niscaya akan dapat mencapai kebenaran-kebenaran iman, maka orang yang beriman seharusnya juga berusaha memahami imannya secara rasional.

Anselmus ingin memperlihatkan bahwa isi ajaran agama (Kristen) bisa dikembangkan berdasarkan alasan-alasan rasional, jadi tanpa bantuan otoritas lain (seperti kitab suci, wahyu atau ajaran para Bapa Gereja). Dalam bukunya yang terkenal, Proslogion, ${ }^{17}$ ia

${ }^{15}$ Linda Smith \& William raeper. A Beginner's Guide to Ideas. Terj. Ide-ide Filsafat dan Agama Dulu dan Sekarang. 40.

16 Robert C. Solomon \& Kathleen M. Higgins, A Short History of Philosophy. Terj. Sejarah Filsafat. 122-123.

${ }^{17}$ Buku ini terbit sekitar tahun 1077 dan memuat hanya satu argumen saja yang memadai dan yang bisa menggantikan banyak argumen tentang pembuktian atas eksistensi Tuhan; argumen ini diharapkan bisa merangkum ciri kemahakuasaan Tuhan. Semua ciri yang bisa dikatakan ada pada Tuhan. Dalam bab pertama, Anselmus berdo'a dengan khusyuk: "Aku bukannya mencoba menyelidiki kebesaran-Mu, ya Tuban, sebab akal budiku sama sekali tidak sebanding dengan kebesaran-Mu itu, tetapi aku ingin sedikit memahami kebenaran-Mu yang dipercayai dan dicintai oleh hatiku. Dan aku tidak bermaksud untuk memahami agar percaya, melainkan: aku percaya agar bisa memabami. Sebab akupun mengakui juga bahwa aku tidak akan mampu memabami, kalau aku tidak percaya". Dengan demikian, sangat jelas bahwa iman menjadi basis filosofis Anselmus. Sebagaimana dikutip oleh Simon. Tuhan Para Filsuf dan Ilmuwan, 25

TAJDID Vol. xv, No. 2, Juli - Desember 2016 |233 
menjelaskan eksistensi Tuhan dengan suatu argumen yang bisa diterima, bahkan juga oleh mereka yang tidak beriman. Berkat Kant, argumen itu kemudian menjadi terkenal dengan nama "argumen ontologis" mengenai eksistensi Tuhan. Di sini Anselmus memahami Tuhan sebagai "sesuatu yang lebih besar dari padanya tidak bisa dipikirkan". Dengan kata lain, bagi Anselmus Tuhan adalah "ada" tertinggi yang dapat dipikirkan manusia. Setinggi, sejauh, dan sedalam apa pun kemampuan berfikir manusia, Tuhan adalah yang paling tinggi, paling jauh dan paling dalam daripada segala sesuatu yang bisa dipikirkan manusia itu.

Kalau Tuhan adalah "sesuatu yang lebih besar daripadanya tidak bisa dipikirkan", maka secara logis mustahillah manusia masih bisa memikirkan suatu yang lain yang lebih besar dari pada Tuhan. Sebab, seandainya saja manusia sanggup memikirkan hal lain yang lebih besar dari pada Tuhan, maka Tuhan --sebagai "sesuatu yang lebih besar dari padanya tidak ada dipikirkan"-- tetap menjadi yang paling besar dari sesuatu lain yang masih bisa kita pikirkan itu ${ }^{18}$. Ada dua pertanyaan yang langsung muncul, yakni: (1) apakah Tuhan yang dimengerti oleh manusia seperti itu adanya? dan (2) jika "ya" apakah itu riil atau hanya dalam pemikiran (akal budi) saja atau serupa dengan ilusi?

Terhadap pertanyaan (1), Anselmus berkata: "orang dungu menyangkalnya dengan mengatakan dalam hati: tidak ada." Namun jika ia mendengar pernyataan bahwa: "Tuhan adalah sesuatu yang lebih besar daripadanya tidak bisa difikirkan", ia menangkap suatu arti dari kata-kata itu, ia memahaminya, ia memikirkan onjek yang diartikan oleh kata-kata itu. Objek itu ada dalam pikirannya, bahkan kalaupun ia menganggapnya tidak ada. Kenyataan bahwa Tuhan itu bisa dimengerti, dipikirkan dan bahkan disanggah, menunjukkan bahwa Tuhan itu ada, setidak-tidaknya ada dalam pemikiran. ${ }^{19}$

Selanjutnya terhadap pertanyaan (2), Anselmus berkata: sebenarnya jika sesuatu itu tidak terdapat selain dalam akal budi,

${ }^{18}$ Pemahaman terhadap kalimat "sesuatu yang lebih besar daripadanya tidak bisa dipikirkan" dapat dicontohkan: ada orang yang memikirkan Tuhan sebesar istana negara, namun kita tau bahwa istana negara bukanlah yang paling besar yang bisa dipikirkan. Masih ada taman monas yang lebih besar daripadanya, lalu apakah Tuhan sebesar taman Monas? Tidak juga, karena masih ada kebun raya Bogor, dan seterusnya. Sehingga kesimpulannya adalah: sejauh apapun jangkauan pemikiran manusia, Tuhan adalah yang paling tinggi dari segala yang bisa dipikirkan manusia itu.

${ }^{19}$ Simon. Tuban Para Filsuf dan Ilmuwan, 26-27. 
orang dapat memikirkan juga bahwa sesuatu tersebut terdapat juga dalam realitas, ini tingkatan yang lebih tinggi. Maksudnya, jika seseorang berpikir tentang sesuatu, maka sesuatu itu tentunya ada juga di luar akal budi atau pemikirannya itu, yakni di dalam realitas. Sebab jika tidak demikian, pemikiran tidak mempunyai onjeknya, dan suatu pemikiran tanpa objek (apapun bentuk objeknya itu) adalah sangat mustahil. Akibatnya, menurut Anselmus tidak ada kesangsian sedikitpun bahwa "sesuatu yang lebih besar daripadanya tidak bisa dipikirkan" itu ada, baik di dalam akal budi maupun di dalam realitas. ${ }^{20}$

Anselmus mengklaim tesisnya sebagai tesis eksistensi Tuhan, yakni bahwa: (1) Tuhan adalah pengada terbesar yang dapat difahami. (2) Lebih besar untuk berada dalam kenyataan daripada hanya di dalam pikiran. (3) Maka Tuhan itu ada. ${ }^{21}$

\section{Thomas Aquinas}

Thomas Aquinas dikenal dengan prinsip "Lima Jalan", sebagai filosof yang hidup pada abad pertengahan yang dikenal dengan filsafat skolastik, Aquinaspun memiliki kecenderungan pemikiran yang dekat dengan agama, bahkan ia merupakan yang terbesar di antara para skolastik. Filsafatnya dikenal sebagai "Thomisme"22, Aquinas tidak menyukai Plato dan menolak bukti ontologis Anselmus, tetapi ia membuat karya-karya Aristoteles dikenal dan diterima oleh para ahli di zamannya. Di dalam karyanya ia lebih sering mengacu pada Aristoteles daripada Kitab Sucinya.

Jalan Pertama, Aquinas memusatkan pada kenyataan perubahan di dunia. "Sekarang segala sesuatu dalam proses perubahan diubah oleh sesuatu yang lain" ungkapnya. Kembali ke Penggerak Pertama

${ }^{20}$ Demikianlah pembuktian ontologis Anselmus yang terkenal itu. Pembuktian ini memperlihatkan bahwa antara iman akan adanya Tuhan dan akal budi tidak bertentangan. Anselmus bersyukur atas pengetahuan ini dengan memanjatkan do'a antara lain: "ya Tuhan, semoga pengetabuanku tentang Engkau semakin mendalam di sini, dan menjadi sempurna kelak di syurga; cintaku pada-Mu semakin bertumbub di sini, dan mengalami kepenuban serta kesempurnaan di sana; sukacitaku di sini menjadi besar dalam pengharapan, dan kelak menjadi penuh senyatanyatanya". Sebagaimana dikutip oleh Simon. Tuban Para Filsuf dan Ilmuwan, 27

${ }^{21}$ Lihat Linda Smith \& William Raeper. A Beginner's Guide to Ideas. Terj. Ideide Filsafat dan Agama Dulu dan Sekarang. 43.

${ }^{22}$ Linda Smith \& William Raeper. A Beginner's Guide to Ideas. Terj. Ide-ide Filsafat dan Agama Dulu dan Sekarang. 46.

TAJDID Vol. xv, No. 2, Juli - Desember 2016 |235 
Aristoteles, Aquinas menyimpulkan: "Bila tangan tidak menggerakkan tongkat, tongkat tidak akan menggerakkan apapun. Jadi, seseorang harus sampai pada sebab atau perubahan pertama yang dia sendiri tidak diubah oleh sesuatu yang lain, dan inilah apa yang dimengerti oleh setiap orang dengan Tuhan." 23

Jalan Kedua, Aquinas memusatkan pada kenyataan bahwa sebab dan akibat ada di dunia. "Sekarang bila anda menghapus suatu sebab, tulis Aquinas, anda juga menghapus akibat-akibatnya, sehingga anda tidak dapat mencapai suatu sebab terakhir, dan juga tidak sampai pada sebab pengantara, kecuali anda mempunyai sebab pertama". Aquinas tidak dapat percaya akan suatu rantai tanpa batas dari sebab-sebab dan akibat-akibat yang merentang kembali ke keabadian, maka seseorang dipaksa untuk memperkirakan sebab pertama tertentu yang oleh setiap orang disebut "Tuhan". ${ }^{24}$

Jalan Ketiga, Aquinas mengambil ide ada dan tiada di dalam dunia. Benda-benda ada, tetapi tidak harus ada. Lebih lagi ada suatu masa sebelum mereka ada dan akan ada waktu setelah mereka berhenti berada. Sekarang tidak mungkin semuanya seperti ini, karena sesuatu agar mejadi ada, suatu ketika tida ada, dan bila semuanya tidak harus ada, pada suatu ketika tidak ada sesuatupun yang ada. Aquinas mengklaim bahwa bila segala sesuatu di dunia dapat ada dan dapat tidak ada, maka harus ada suatu saat bila tidak ada sesuatupun yang ada. Tidak mungkin sesuatu muncul dari ketiadaan. Maka seseprang dipaksa untuk menduga adanya sesuatu yang harus ada, dan keberadaan-Nya itu bukan diberikan oleh yang lain kecuali diri-Nya sendiri, bahkan Dia sendirilah yang menjadi sebab adanya hal-hal lain. Bagi Aquinas, seperti juga Anselmus, benda-benda di dunia mempunyai eksistensi kontingen (dapat ada atau dapat tidak), tetapi hanya Tuhan yang mempunyai eksistensi niscaya (Tuhan harus ada). Seandainya Tuhan tidak ada maka tidak ada sesuatupun yang dapat ada, sebab ciptaan tergantung pada eksistensi nisacaya Tuhan agar mereka dapat ada. ${ }^{25}$

Jalan Keempat, dipusatkan pada tingkat-tingkat kebaikan dan kesempurnaan di dunia. "Misalnya, benda-benda semakin panas mereka mendekati yang paling panas. Maka sesuatu adalah yang paling

${ }^{23}$ Linda Smith \& William raeper. A Beginner's Guide to Ideas. Terj. Ide-ide Filsafat dan Agama Dulu dan Sekarang. 48-49.

${ }^{24}$ Linda Smith \& William raeper. A Beginner's Guide to Idea, 49.

${ }^{25}$ Linda Smith \& William raeper. A Beginner's Guide to Idea, 49. 
benar atau paling tidak paling baik dan paling mulia di antara bendabenda, dan oleh karenanya paling penuh dalam adanya". Aquinas meneruskannya untuk mengatakan "Maka, ada sesuatu yang menyebabkan keberadaan, kebaikan, dan kesempurnaan apapun yang ada dalam benda-benda. Ini disebut "Tuhan". ${ }^{26}$

Jalan Kelima, menunjuk pada tatanan dan tujuan di dalam alam. "Sebab tingkah laku mereka hampir tidak berubah, dan praktis selalu menjadi baik; yang menunjukkan bahwa mereka benar-benar mengarah kepada satu tujuan, dan tidak hanya terjadi demikian karena kebetulan. Tidak ada sesuatupun yang tidak memiliki kesadaran mengarah pada suatu tujuan, kecuali diarahkan oleh seseorang dengan kesadaran dan pengertian; anak panah misalnya, mensyaratkan adanya seorang pemanah. Maka, segala sesuatu di alam semesta diarahkan pada tujuannya oleh seseorang dengan pemahaman, dan ini disebut "Tuhan". ${ }^{27}$

Itulah lima jalan yang merupakan bukti-bukti ilmiah Aquinas tentang eksistensi Tuhan. Bukti-bukti Aquinas menjadi patokan dalam mendemonstrasikan eksistensi Tuhan untuk kurun waktu beberapa abad. Bahkan sekarang beberapa pemikir Kristen percaya bahwa mungkinlah untuk membentuk teologi "kodrati" yang melihat dunia dan mencoba untuk mendeduksikan Tuhan. Namun pemikiran Aquinas ini mulai mendapat serangan keras pada abad ke -18 , seperti oleh David Hume (1711-1776).

\section{Rene Descartes}

Rene Descartes merupakan filosof rasionalis besar pertama, yang mengawali filsafatnya dengan suatu pertanyaan: Apakah ada metode yang pasti sebagai basis untuk melakukan refleksi filosofis? Untuk menjawab pertanyaan ini Descartes menjalankan apa yang kemudian dinamakan sikap keragu-raguan radikal. Dengan sikap ini ia menganggap bahwa segala sesuatu hanyalah tipuan, dan tidak mau menerima apapun sebagai sesuatu yang benar, jika tidak memahaminya dengan jelas dan terpilah-pilah. Lebih lanjut kemudian ia mempertanyakan kalau segala sesuatu diragu-ragukan secara radikal keberadaannya, ada satu hal yang sama sekali tidak bisa diraguragukan lagi dan harus diterima secara mutlak, yakni kenyataan bahwa "aku" yang tengah meragukan segala sesuatu ini ada. Orang bisa

\footnotetext{
${ }^{26}$ Linda Smith \& William raeper. A Beginner's Guide to Idea, 50.

${ }^{27}$ Linda Smith \& William raeper. A Beginner's Guide to Idea, 50.
} 
menyangkal segala sesuatu, namun ia tidak bisa menyangkal keberadaan dirinya sendiri. Dari sinilah muncul kesimpulan filosofisnya yang terkenal "Aku berfikir, maka Aku ada". ${ }^{28}$

Lalu bagaimana manusia sampai pada penerimaan adanya Tuhan? Descartes menjelaskan dua jalan; Pertama, secara kausal menurut skema sebab akibat. Bagi Descartes jelas bahwa manusia menemukan dalam dirinya ide kesempurnaan. Dari fakta bahwa manusia senantiasa mau mencari kebenaran yang jelas dan terpilahpilah, terungkap kenyataan bahwa ia mau mencapai kesempurnaan pengetahuan, di satu pihak, namun sekaligus juga di lain pihak, diimplikasikan bahwa dirinya sendiri yang serba terbatas ini bukanlah sumber kesempurnaan itu. Maka, kesimpulan Descartes, mesti ada penyebab pertama yang bukan "aku" dan yang menanamkan dalam diriku ide kesempurnaan tadi. Dia itulah Tuhan: Ide Tuhan bagi Descartes merupakan suatu Ide yang dimiliki manusia sebagai bawaan.

Kedua, secara ontologis menurut skema "ada=eksistensi". Di sini Descartes mengambil alih argumen Anselmus yang disebut argumen ontologis. Tentu saja dengan menerapkan prinsip kejelasan dan keterpilahan yang Descartes temukan sendiri dalam fahamnya "cogito ergo sum, sive existo" ("aku berfikir maka aku ada, atau lebih tepat aku bereksistensi"). Kalau manusia mengatakan bahwa Tuhan itu sempurna, maka mestinya ada seseorang yang menyandang predikat ini. Tidak mungkin predikat atau sifat "sempurna" berdiri sendiri, tanpa ada kaitan apapun dengan suatu entitas yang riil eksistensinya. Maka, harus disimpulkan bahwa Tuhan itu ada dan bereksistensi. Bukan itu saja, bagi Descartes yang mengutamakan pengetahuan yang jelas dan terpilah-pilah, faham Tuhan yang sempurna ini bukan saja menyangkut kesempurnaan pengetahuan, melainkan juga kapasitas moralnya. ${ }^{29}$

Dalam diskusi filosofis, pembuktian eksistensi Tuhan menurut Descartes yang berangkat dari kesadaran Subjek ini bukan tanpa masalah. Diakui kebenarannya bahwa pemikiran mengenai Tuhan sebagai yang maha sempurna memang tidak dapat berjalan tanpa sekaligus memikirkannya sebagai sesuatu yang bereksistensi. Namun pertanyaannya tetap: apakah cara berfikir mengenai Tuhan semacam itu sungguh menunjukkan secara meyakinkan kenyataan objektif

${ }^{28}$ Simon. Tuban Para Filsuf dan Ilmuwan, 21

${ }^{29}$ Simon. Tuban Para Filsuf dan Ilmuwan, 23 
adanya Tuhan, atau hanya merupakan suatu kemungkinan (bukan keniscayaan) bahwa Tuhan itu ada.

\section{Benedict Spinoza}

Benedict Spinoza memulai filsafatnya dari pengertian "Substansi". Ini seolah-olah menjawab problem filsafat Descartes tentang bagaimanakah Tuhan, jiwa dan dunia material bisa dipikirkan sebagai satu kesatuan utuh? Spinoza menjawab persoalan ini. Ia mendefinisikan substansi sebagai "sesuatu yang ada dalam dirinya sendiri dan dipikirkan oleh dirinya sendiri, artinya: sesuatu yang konsepnya tidak membutubkan konsep lain untuk membentuknya".30 Jadi, substansi adalah apa yang berdiri sendiri dan ada oleh dirinya sendiri, sebab bahkan dari konsepnya pun ia tidak bisa bergantung pada sesuatu yang lain. Spinoza membedakan substansi dengan atribut, yakni: sifat atau ciri corak yang melekat pada substansi, dan karenanya tergantung padanya.

Sifat substansi adalah abadi, tidak terbatas, mutlak (artinya: sama sekali tidak tergantung pada yang lain) dan tunggal-utuh. Menurut Spinoza, hanya ada satu yang memenuhi semua denfinisi ini: yakni Tuhan, hanya Tuhan yang mempunyai sifat abadi, tidak terbatas, mutlak, tunggal dan utuh. Implikasinya jelas, Spinoza menolak Tuhan yang bersifat personal. Selanjutnya, Spinoza mengajarkan kalau Tuhan adalah satu-satunya substansi, maka segala yang ada harus dikatakan berasal daripada-Nya. Ini berarti, semua gejala pluralitas dalam alam baik yang bersifat jasmaniah (manusia, flora dan fauna, bintang gemintang dan lain sebagainya) maupun yang bersifat rohaniah (pemikiran, perasaan, bahkan kehendak) bukanlah hal-hal yang berdiri sendiri, melainkan tergantung "ada"-nya secara mutlak pada Tuhan. Untuk menyebut semua gejala ini, Spinoza sendiri memakai istilah modi. ${ }^{31}$ Maka, semua realitas dan gejala yang biasa ditemukan dalam alam hanyalah modi saja dari Tuhan sebagai substansi tunggal. Dengan kata lain, alam dengan segala isinya adalah identik dengan Tuhan secara prinsipiil.

Kata kunci ajaran Spinoza yang terkenal adalah "Deus sive natur" (Tuhan atau alam). Yang berbeda hanyalah sudut pandang atau

\footnotetext{
${ }^{30}$ Lihat. Simon. Tuhan Para Filsuf dan Ilmuwan, 29

${ }^{31}$ Berasal dari kata "modus" bentuk singular dari kata benda latin yang berati "cara". Modi berarti berbagai bentuk atau cara berada dari substansi ya ng satu dan sama.
}

TAJDID Vol. XV, No. 2, Juli - Desember 2016|239 
istilahnya saja. Sebagai Tuhan, alam adalah "natura naturans" (Alam yang melahirkan). Sebagai dirinya sendiri, alam adalah "natura naturada" (alam yang dilahirkan). Substansinya sama dan satu: Tuhan atau (juga) alam. Spinoza membantah ajaran Descartes bahwa realitas seluruhnya terdiri dari tiga substansi(Tuhan, jiwa dan materi), bagi Spinoza hanya ada satu substansi saja, yakni Tuhan/alam, selain itu persoalan dualisme dalam filsafat Descartes berhasil juga diatasi, menurut Spinoza Descartes keliru memandang pemikiran (hakikat jiwa) dan keluasan (hakikat tubuh) sebagai dua substansi yang berada pada manusia. Yang benar, menurut Spinoza, jiwa/pemikiran dan tubuh/keluasan bukanlah dua substansi, melainkan dua aktribut ilahi, yakni dua dari sekian banyak sifat Tuhan/alam yang bisa di tangkap manusia. ${ }^{32}$

\section{Immanuel Kant}

Immanuel Kant adalah filosof yang paling berpengaruh dalam sejarah filsafat modern. Kant terkenal dan berpengaruh berkat filsafat moral dan hubungan antara moral dan eksistensi Tuhan. Apa hubungan moral dengan Tuhan? Kant mempunyai beberapa variasi jawaban atas satu pertanyaan ini. Di sini akan disampaikan dua ajaran Kant yang terkenal tentang hal itu.

Pertama, Tuhan dan suara hati. Kesadaran moral mulai dengan kewajiban yang mutlak sifatnya. Kewajiban yang mengikat seperti ini hanya mungkin dibebankan kepada manusia oleh seorang pribadi lain yang juga bersifat mutlak. Pribadi itu tentunya bukan manusia, sebab manusia adalah makhluk terbatas. Maka, kesadaran moral dan suara hati mengandaikan adanya seorang pribadi yang perintah-Nya wajib ditaati. Pribadi itu adalah Tuhan. Dengan bertindak moral dan dengan mengikuti suara hati, manusia mengakui kehadiran Tuhan. Kesadaran akan kehadiran Tuhan ada di luar jangkauan pemikiran murni yang bersifat teoretis. Dalam suara hati, manusia sadar akan tuntunan dari Tuhan yang memberi dan menjamin hukum abadi. Bagi Kant, suara hati adalah kesadaran akan suatu otoritas yang secara mutlak mengikat manusia pada kewajibannya, sedangkan Tuhan adalah instansi moral yang memberi kepada manusia kemutlakan pemerintah kewajiban suara hatinya.

Kedua, Tuhan dan tujuan moralitas. Bagi Kant, kesadaran moral mewajibkan manusia untuk mengupayakan "kebaikan tertinggi"

${ }^{32}$ Lihat. Simon. Tuban Para Filsuf dan Ilmuwan, 30. 
(summum bonum) atau kebahagiaan sempurna. ${ }^{33}$ Namun kebaikan tertinggi atau kebahagiaan akhir itu, menurut Kant, tidak pernah terealisasi di dunia ini karena adanya kejahatan. Kalau memang demikian, maka yang menjadi persoalan adalah: Apakah perbuatan moral manusia di dunia ini akan sia - sia saja, sebab cita-cita atau tujuan moralitas itu tidak mungkin tercapai, padahal justru itu yang wajib dikejar? Jawaban Kant adalah agar kebaikan moral manusia dengan kebahagiaan sempurna itu berhubungan, manusia harus menerima adanya postulat ini: kebebasan kehendak, keabadian jiwa dan adanya Tuhan.

Mustahillah suatu kewajiban moral tanpa kebebasan kehendak; hukum moral adalah hukum yang di dalamnya manusia bertindak berdasarkan prinsip yang diyakininya sendiri dan justru karena kebebasan kehendaklah manusia bisa berbuat. Keabadian jiwa menyebabkan manusia sebagai pelaku tindakan moral bisa mencapai "kebaikan tertinggi" atau kebahagiaan sempurna yang tidak mungkin dicapainya di dunia ini. Dan akhirnya, Tuban adalah pribadi yang menjamin bahwa orang yang bertindak baik demi kewajiban moral akan mengalami kebahagiaan sempurna. Dengan kata lain, kebahagian ini disediakan Tuhan untuk manusia yang bertindak baik secara moral. Kalau Tuhan disangkal eksistensinya, moralitas akan absurd, sebab "nasib" manusia yang hidupnya baik secara moral akan sama saja dengan "nasib" manusia yang jahat. Lalu, untuk apa manusia masih mau susah-susah hidup baik?34

\section{Alfred North Whitehead}

Whitehead pada awalnya mengkritik realitas materialisme ilmiah (scientific materialism). Ia mengedepankan ide tentang entitas aktual sebagai alternatif konsep substansi doktrin materialisme, entitas aktual berfungsi sebagai realitas final yang terus berproses menuju kebaruan dengan bantuan entitas-entitas aktual lainnya, sehingga antara satu entitas aktual dengan entitas aktual lainnya terjadi interkoneksi dan interdependensi yang saling berelasi. Menurutnya materialisme ilmiah telah memilah-milah realitas atas partikel atomis, sehingga penjelasan tentang realitas dilakukan dengan hanya merujuk kepada elemenelemen material yang terikat pada ruang dan waktu, pada hakikatnya

\footnotetext{
${ }^{33}$ Bukan kebahagian dalam empiris seperti kesenangan, kesehatan, kekayaan atau kekuasaan -- semua ini ditolak Kant sebagai dasar impreatif kategoris. Lihat. Simon. Tuhan Para Filsuf dan Ilmuwan, 60.

${ }^{34}$ Lihat. Simon. Tuhan Para Filsuf dan Ilmuwan, 61.
}

TAJDID Vol. XV, No. 2, Juli - Desember $2016 \mid 241$ 
realitas bukanlah sekedar satuan material yang terikat pada ruang dan waktu, karena unsur-unsur realitas saling terjalin, merujuk dan membentuk satu kesatuan yang utuh. ${ }^{35}$

Teori entitas aktual ini kemudian melahirkan teori prehensi (prehension), yakni fakta bahwa adanya keterjalinan antara unsur-unsur yang ada di alam. Ini merupakan suatu cara pandang terhadap adanya pengaruh-pengaruh kausal dari masa lampau sebagai bagian dari esensinya sendiri dalam membentuk entitas aktual. Setiap prehensi dapat dianalisis menjadi tiga faktor utama, yakni (1) subjek yang berprehensi, yakni entitas aktual yang padanya prehensi tersebut menjadi suatu elemen kongkrit, (2) data awal yang ditangkap atau diterima melalui prehensi yang bersangkutan, dan (3) forma subjektif, yaitu reaksi internal si subjek terhadap data yang ditangkap.

Konsep ketuhanan berikutnya yang mempunyai kedudukan penting dalam sistem metafisika Whitehead adalah objek-objek abadi. Objek-objek abadi memiliki hakikat yang abstrak, yaitu pola-pola hubungan yang tetap, abadi, tidak terikat oleh ruang dan waktu, bersifat objektif dan merupakan prinsip-prinsip umum (a general principle). Ia mencontohkan tentang dirinya, ketika berfikir ia mulai dengan suatu konsep, baru kemudian memilih kata-kata sebagai perwujudannya, seperti ungkapannya; "saya tidak berfikir dalam katakata, saya mulai dengan konsep-konsep, baru kemudian memunculkannya dalam bahasa dan kata-kata yang sering kali sangat sulit."

Kreativitas adalah elemen pemikiran metafisis Whitehead berikutnya setelah kedua elemen di atas, konsep kreativitas (creativity) sebagai aktualisasi potensi, yang merupakan penghubung dan pemersatu kedua elemen metafisis sebelumnya. Kreativitas adalah landasan metafisika filsafat organism dan merupakan suatu bentuk aktivitas sintesis yang membentuk kesatuan alam semesta. Tuhan adalah sebuah fakta lengkap yang sistematis, sebagai entitas aktual non temporal, yang dalam bahasa agama-agama dirasionalisasikan

${ }^{35}$ Tulisan mengenai filsafat Ketuhanan Whitehead disarikan dari disertasi Naupal. Pemikiran Metafisis Ibn Al'Arabi dan Whitehead. Disertasi UIN Syarif Hidayatullah Jakarta, 2009 Bandingkan dengan Simon. Tuban Para Filsuf dan Ilmuwan, 129-139 dan lihat Whitehead. Religion in the Making. Terj. Mencari Tuban Sepanjang Zaman: Dari Agama Kesukuan Hingga Agama Universal. (Bandung: Mizan, 2009). 
dengan sebutan Tuhan. Dalam filsafat proses, 36 Tuhan sebagai pencipta diartikan bahwa Tuhan menjadi asal mula atau pangkal yang dari-Nya memberikan adanya aktivitas kreativitas, dan Tuhan merupakan sifat-sifat yang primordial dan abadi.

Alam semesta merupakan sesuatu yang organis dan kreatif, dan menurutnya kreativitas alam berlangsung melalui empat tahapan, (1) fase konseptual, tidak aktual dan tak terbatas. (2) fase temporal, berupa keaneka ragaman aktualitas, di sini aktualitas sepenuhnya tercapai, namun sifat solidaritasnya satu sama lainnya belum terlihat. (3) fase aktualitas sempurna, di mana keanekaragaman menemukan kesatuannya yang abadi tanpa kehilangan identitas individualnya, dan (4) fase selesainya aktifitas kreativitas, di mana aktualitas yang telah sempurna yang mempengaruhi dunia temporal. Kreativitas dan Tuhan merupakan elemen yang berbeda, tetapi saling merujuk. Tuhan memberikan karakter aktual kepada kreativitas dan ditentukan serta dibatasi oleh Tuhan, kreativitaslah yang akan mempertemukan kembali semua pasangan yang kontras, yang tetap dan yang berubah, yang satu dan yang banyak, Tuhan dan dunia.

Eksistensi Tuhan adalah irasional terakhir, Tuhan bukanlah realitas kongkrit, tetapi Dia menjadi dasar bagi setiap aktualitas yang kongkrit. Hakikat-Nya tidak dapat dijelaskan, sebab hakikat-Nya itu justru menjadi dasar rasionalitas. Tuhan adalah dipolar, dia merupakan sesuatu yang beraspek awali (primordial) dan sekaligus beraspek akhiri (consequent). Sebagai aspek awali, objek-objek abadi secara independen dalam hakikat primordial Tuhan, dan sebagai aspek akhiri, realitas Tuhan meliputi semua pengalaman fisik. Penjelasan panjang lebar mengenai aspek awali dan akhiri ini menggambarkan kesempurnaan Tuhan, kesempurnaan Tuhan bukan karena Dia transenden, tapi justru kesempurnaan-Nya ditemukan keterbukaan dan keterkaitan-Nya dengan dunia. Dia yang membuka keagungan-Nya kepada semua ciptaan-Nya. ${ }^{37}$

Pengertian yang dapat diungkapkan dari apa yang terkandung dalam konsep Whitehead tentang hubungan Tuhan dan alam, antara lain: (1) Memperlihatkan bahwa antara Tuhan dan alam mempunyai keterkaitan, hubungan korelatif dalam proses harmonisasi, (2) memperlihatkan hubungan Tuhan dan alam dalam dua proposisi sekaligus, Tuhan sama dengan alam dan Tuhan tidak sama dengan

${ }^{36}$ Lihat. Simon. Tuban Para Filsuf dan Ilmuwan, 131-132.

${ }^{37}$ Lihat. Simon. Tuban Para Filsuf dan Ilmuwan, 133-135.

TAJDID Vol. XV, No. 2, Juli - Desember 2016 |243 
alam, (3) hubungan Tuhan dengan alam tidak bisa digambarkan secara linear, melainkan dalam kategori proses, dan (4) hubungan Tuhan dan alam terbentuk dengan keserasian dan keseimbangan, sehingga secara spiritual menghidupkan kesadaran spiritual yang inheren dalam diri manusia dalam membangun hubungan timbal balik dengan sesama dan alam sekitar, atau dapat disebutkan sebagai usaha untuk mengedepankan etika lingkungan dalam melihat alam semesta.

\section{Kesimpulan}

Demikianlah pembahasan tentang argumen filosofis eksistensi Tuhan menurut beberapa filosof Barat. Dalam sejarah filsafat, adatidaknya Tuhan sangat sering dipersoalkan. Sehingga Blaise Pascal (1623-1662) menyebutkan bahwa keseluruhan realitas tidak bisa dijelaskan hanya dengan rasio, karena bila itu dilakukan akan terjadi banyak hal yang bertentangan. Rasio saja tidak cukup untuk memahami segalanya. Lebih penting dari rasio adalah "hati". Dengan rasio manusia hanya bisa memahami kebenaran matematis dan ilmu alam, tetapi dengan hati, manusia akan mampu memahami kebenarankebenaran yang melampaui semua kebenaran itu, terutama tentang Tuhan. ${ }^{38}$

Pascal menyebutkan bahwa kaum terpelajar yang tidak percaya dan mencemooh orang sederhana yang beriman pada Tuhan, tetapi tidak pernah membuktikannya sendiri. Pascal mengajukan argumen "pertaruhan". Menurutnya manusia dalam memutuskan menerima atau menolak Tuhan, harusnya menerima adanya Tuhan sebagaimana yang ia lakukan. Dengan pertaruhan itu, maka jika manusia yang menerima atau percaya adanya Tuhan menang (artinya Tuhan memang ada), manusia memang benar-benar memperoleh kemenangan dan menikmati hasilnya, yakni hidup bersama Tuhan yang diimaninya.

Jika sebaliknya manusia yang beriman itu kalah (artinya Tuhan ternyata tidak ada), orang beriman tidak rugi apapun dan sedikitpun. Sebab sama seperti dalam setiap pertaruhan, bertaruh demi Tuhan juga menyebabkan kita menunda dulu segala kesenangan hidup, dengan hidup baik dan boleh berharap akan kemenangan nanti. Kalu

${ }^{38} \mathrm{Hati}$ di sini tidak difahami sebagai pusat emosi, tetapi merupakan pusat aktivitas jiwa manusia yang terdalam yang mampu menangkap sesuatu secara intuitif dan spontan; hati adalah inti eksistensi. Lihat. Simon. Tuhan Para Filsuf dan Ilmuwan, 36. 
ternyata orang beriman itu kalah dalam pertaruhan atau permainan, hidup baik itu sendiri sudah merupakan keutamaan yang berguna dan membahagiakan hidup manusia itu sendiri dan orang lain di dunia ini.

Dan akhirnya, mengutip Karl Jaspers (1883-1969), yang mengajukan teori transendensi Tuhan, dan mengkritik "iman berdasarkan wahyu semata" dengan "iman filosofis" mengatakan bahwa : "Dogma dan syahadat itu benar bukan karena diformulasikan, melainkan karena sebaliknya: Dogma dan syabadat itu diformulasikan karena benar".

\section{Daftar Pustaka}

Amsal, Bakhtiar. Filsafat Agama, Wisata Pemikiran dan Kepercayaan Manusia. Jakarta: Raja Grafindo Persada, 2009.

Greenspan, Louis \& Stefan Anderson. Russell on Religion. Terj. Bertuban Tanpa Agama, Esai-Esai Bertrand Russell. Yogyakarta: Resist Book, 2009.

Hick, John H. Philosophy of Religion. Temple: Temple University Press, 1973

J.J.C. Smart \& J.J. Haldane. Atheisme and Theisme, Second Edition. Oxford: Blackwell Publishing, 2003

Murray, Michael J. \& Michael Rea. An Introduction to The Philosophy of Religion. Cambridge, Cambridge University Press, 2008.

Nasution, Harun.Falsafat Agama. Jakarta: Bulan Bintang, 2003.

Naupal. "Pemikiran Metafisis Ibn Al'Arabi dan Whitehead." Disertasi UIN Syarif Hidayatullah Jakarta, 2009

Norman L. Geisler. Philosophy of Religion. Michigan: The Zondervan Corporation, 1974.

Peterson, Michael L. \& Raymond J. Vanarragon (Ed). Contemporary Debates in Philosophy of Religion. Oxford: Blackwell Publishing Ltd, 2004

Smith, Linda \& William Raeper. A Beginner's Guide to Ideas. Terj. Ide-ide Filsafat dan Agama Dulu dan Sekarang. Yogyakarta: Penerbit Kanisius, 2004.

Sobel, Jordan Howard. Logic and Theism, Arguments For and Against Beliefs in God. Cambridge: Cambridge University Press, tt

TAJDID vol. XV, No. 2, Juli - Desember $2016 \mid 245$ 


\section{Supian}

Solomon, Robert C. \& Kathleen M. Higgins, A Short History of Philosophy. Terj. Sejarah Filsafat. Yogyakarta: Yayasan Bentang Budaya, 2002

Tjahyadi, Simon Petrus L. Tuhan Para Filsuf dan Ilmuwan, Dari Descartes Sampai Whitehead. Cet. 5. Yogyakarta: Kanisius, 2011

Thiselton, Anthony C. A Concise Encyclopedia of the Philosophy of Religion. Oxford: One World, 2002.

Vedder, Ben. Heidegger's Philosophy of Religion, From God to Gods. Pennsylvania: Duquesne University Press, 2006.

Whitehead. Religion in the Making. Terj. Mencari Tuban Sepanjang Zaman: Dari Agama Kesukuan Hingga Agama Universal. Bandung: Mizan, 2009.

William J. Wainwright (Ed). The Oxford Handbook of Philosophy of Religion. Oxford: Oxford University Press, 2002.

Yandell, Keith E. Philosophy of Religion, A Contemporary Introduction. London \& New York: Routledge, 1999. 